\title{
Pendampingan Pasien Tuberkulosis Resisten Obat (TBC-RO) Melalui Strategi Komunikasi Interpersonal Organisasi Mantan Pasien
}

\author{
Assisting Multidrug-Resistant Tuberculosis (MDR-TB) Patients \\ Through Interpersonal Communication Strategies of Former \\ Patient Organizations (Organisasi Mantan Pasien)
}

Khuswatun Hasanah
Virginia Ayu Sagita
Universitas Pembangunan Nasional Veteran Yogyakarta
J1. Babarsari, Tambakbayan No. 2, Janti, Caturtunggal, Kec. Depok, Kab.
Sleman, Daerah Istimewa Yogyakarta, 55281
khuswatun@upnyk.ac.id
virginia@ upnyk.ac.id

\begin{abstract}
This study aims to examine the communication strategies carried out by the organization of former drug resistant tuberculosis patients Multidrug-Resistant Tuberculosis (MDR-TB) in assisting $M D R-T B$ patients, both related to treatment, access to services, and about social impacts during treatment. As an innovation that was born in collaboration with the TB Sub Directorate of the Ministry of Health together with the Indonesia Challenge TB $(C T B)$, the organization of ex-patients plays an important role in providing assistance. Because the treatment for MDR-TB patients is not easy in terms of the length of the treatment period, side effects of treatment, access to services, to other social problems. The former patient organization is present as a group that has undergone MDR-TB treatment periods so that the experience of delivering MDR-TB patients who are on medication has the same perception and motivation related to healing. The method used is a qualitative descriptive approach. Data obtained through observation, in-depth interviews (indepth interview), and
\end{abstract}


documentation of all patient organization activities supported by $C T B$ in 6 provinces in Indonesia. The results showed that through the similarity of fields of experience, the accompanying messages conveyed by patient organizations were channeled effectively. This is also supported by the interpersonal strategy of the organization of the former patient who plays himself as a peer educator in providing assistance and motivation for treatment. The communication is carried out by door to door (home visit), hospital visits, and through focus group discussions. This study also confirms the theory of Message Design Logic by Barbara O'Keefe that with the Rhetorical Message Design Logic, the message delivered is emphasized to achieve its goals not just the occurrence of response or reciprocity. In this case, supported by a shared experience, the motivation to complete treatment for TB patients will be more effective and get a good response.

Keywords: Tuberculosis, MDR-TB, Interpersonal Communication, Field of Experience

\begin{abstract}
Abstraksi
Penelitian ini bertujuan mengkaji strategi komunikasi yang dilakukan oleh organisasi mantan pasien tuberkulosis resisten obat (TBC-RO) dalam melakukan pendampingan terhadap pasien TBC-RO, baik terkait pengobatan, akses layanan, maupun perihal dampak sosial semasa pengobatan. Sebagai inovasi yang dilahirkan atas kolaborasi Sub Direktorat TBC Kementerian Kesehatan bersama dengan Challenge TB (CTB) Indonesia, organisasi mantan pasien memegang peranan penting dalam melakukan pendampingan. Pasalnya, pengobatan bagi pasien TBC-RO tidak mudah dari sisi lamanya jangka waktu pengobatan, efek samping pengobatan, akses layanan, hingga masalah sosial lainnya. Organisasi mantan pasien hadir sebagai kelompok yang pernah menjalani masa-masa pengobatan TBCRO sehingga pengalaman mengantarkan pasien TBC-RO yang sedang dalam pengobatan memiliki persepsi dan motivasi yang sama terkait kesembuhan. Metode yang digunakan adalah
\end{abstract}


pendekatan deskriptif kualitatif. Data diperoleh melalui observasi, wawancara mendalam (indepth interview), dan dokumentasi dari segala kegiatan organisasi pasien dukungan CTB di 6 provinsi di Indonesia. Hasil penelitian menunjukkan bahwa melalui adanya kesamaan field of experience, pesan pendampingan yang disampaikan oleh organisasi pasien tersalurkan dengan efektif. Hal ini didukung pula oleh strategi interpersonal organisasi mantan pasien yang memerankan diri sebagai peer educator dalam memberi pendampingan dan motivasi pengobatan. Adapun komunikasi tersebut dilakukan secara door to door (home visit), kunjungan ke rumah sakit, dan melalui diskusi kelompok terarah. Penelitian ini sekaligus mengonfirmasi teori Message Design Logic oleh Barbara O'Keefe bahwa dengan gaya komunikasi logika desain pesan retorika, pesan yang disampaikan ditekankan untuk mencapai tujuannya bukan sekadar hanya terjadinya respon atau timbal balik saja. Dalam hal ini, didukung oleh kesamaan pengalaman maka motivasi menuntaskan pengobatan bagi pasien TBC-RO akan lebih efektif dan mendapatkan respon yang baik.

\section{Kata Kunci: Tuberkulosis, TBC-RO, Komunikasi Interpersonal, Field of Experience}

\section{PENDAHULUAN}

Tuberkulosis (TBC) merupakan isu internasional yang banyak disoroti. Buktinya pada 1993, organisasi kesehatan internasional atau World Health Organization (WHO) mendeklarasikan TBC sebagai global health emergency. Sementara itu di Indonesia, selain persoalan Stunting dan Imunisasi, TBC turut menjadi isu prioritas yang gencar menjadi perhatian pemerintah. TBC sendiri merupakan penyakit menular akibat kuman Mycobacterium Tuberculosis (Mtb). Penularan 
penyakit ini dapat melalui udara, dari pasien infeksius ke orangorang sekelilingnya. Satu pasien TBC terkonfirmasi bakteriologis yang tidak diobati secara tepat dan berkualitas maka berpotensi menginfeksi hingga 10 orang per tahunnya.

Indonesia sebagai salah satu negara dengan beban TBC tertinggi di dunia, memiliki prevalensi penyakit TBC sekitar 142 per 100.000 penduduk (Kemenkes, 2019). Di dunia, pada 2019 terdapat 1,7 miliar penduduk yang terinfeksi TBC (Global TB Report, 2019). Hal ini menyebabkan program penanggulangan TBC menjadi penting. Hingga kini, Kementerian Kesehatan Republik Indonesia (Kemenkes RI) terus memperbarui strategi untuk menuntaskan kasus TBC ini sehingga target Indonesia Bebas TBC 2030 dapat tercapai. Pada 1995 organisasi kesehatan internasional World Health Organization (WHO) telah merekomendasikan strategi DOTS sebagai salah satu strategi penanggulangan TBC sekaligus terbukti sebagai strategi penanggulangan yang ekonomis dan efektif. Di Indonesia, salah satu strategi menuju target tersebut yakni penemuan pasien yang bukan hanya secara "aktif dengan aktif promotif", tetapi juga melalui "penemuan aktif secara intensif dan masif berbasis keluarga dan masyarakat" dengan tetap memperhatikan dan mempertahankan layanan yang bermutu sesuai standar.

Sebuah permasalahan seputar TBC yang sangat penting disoroti yakni mengenai Tuberkulosis Resisten Obat (TBC-RO). Adapun TBC-RO dapat diakibatkan oleh sejumlah faktor di antaranya yakni tidak teratur menelan obat anti tuberkulosis 
(OAT) sesuai panduan yang dianjurkan oleh petugas kesehatan, menghentikan pengobatan secara sepihak sebelum waktunya sehingga mengalami kekebalan terhadap OAT, tidak mematuhi anjuran dokter atau petugas kesehatan, gangguan penyerapan obat, dan tertular dari pasien TBC-RO lainnya (menular melalui udara saat pasien TBC batuk atau bersin).

Menurut data yang dihimpun oleh KNCV Tuberculosis Foundation Indonesia, penemuan kasus terduga TBC-RO dari 2009 hingga 2015 secara nasional mengalami peningkatan, begitupun dengan pasien TBC-RO yang diobati. Sementara kasus penemuan TBC-RO nasional menurun di tahun 2016. Selain itu, data WHO juga menunjukkan bahwa angka keberhasilan pengobatan TBC-RO di Indonesia sangat rendah yakni sekitar 2.500 pasien yang sembuh dari total 23.000 penderita TBC-RO pada 2018.

Adapun beberapa alasan rendahnya keberhasilan pengobatan yang dikemukakan oleh Kepala Sub Direktorat Tuberkulosis Kemenkes RI, dr. Imran Pambudi yakni karena terlambatnya diagnosis dan memulai pengobatan serta tingginya angka putus berobat. Menurutnya, kurangnya dukungan dari orang sekitar juga sangat berpengaruh pada angka keberhasilan pengobatan pasien TBC-RO, terutama dukungan psikis dan mental dalam menyelesaikan rangkaian pengobatan.

Pengobatan TBC sensitif obat memang membutuhkan waktu yang cukup lama dibandingkan pengobatan infeksi bakteri lainnya, yakni minimal 6-9 bulan pengobatan. Selain itu, efek 
samping yang ditimbulkan dari penggunaan OAT-pun tidak sedikit, misalnya mual, asam urat naik, sakit kepala, dan telinga sering berdengung. Dari segi sosial, seorang pasien TBC perlu menjalani pengobatan rutin ke rumah sakit sehingga harus menggunakan waktu kegiatan sehari-hari. Hal-hal demikian yang kerap kali membuat pasien tidak menyelesaikan pengobatannya sehingga berpotensi mengalami kekambuhan bahkan resistensi terhadap OAT.

Salah satu kegiatan yang penting untuk mendukung keberhasilan strategi bebas TBC 2030 yakni pelacakan dan investigasi kontak untuk menemukan kasus-kasus yang belum terdeteksi. Sementara untuk mendukung keberhasilan pengobatan TBC-RO, upaya yang perlu dilakukan adalah melakukan pendekatan dan edukasi atau penyuluhan kepada pasien TBC tentang pentingnya menyelesaikan setiap tahapan pengobatan TBC. Pengetahuan ini akan sangat berguna dalam meningkatkan keberhasilan pengobatan TBC sebab terdapat asumsi bahwa semakin baik tingkat pengetahuan penyakit TBC beserta pengobatannya maka orang yang menderita penyakit TBC akan semakin sadar untuk menjalani program pengobatan secara teratur (Nugroho, 2011; Anton 2008; Mitnick, 2008).

Meskipun demikian, ketika informasi tahapan pengobatan telah sampai kepada pasien TBC, tidak serta-merta pasien TBC akan fokus dan bertekad bulat dalam menyelesaikan pengobatannya seiring adanya efek samping pengobatan yang tidak ringan. Sehingga dalam hal ini, kehadiran pihak lain untuk 
memotivasi pasien TBC dalam menuntaskan pengobatan sangat diperlukan. Bukan hanya memotivasi, kehadiran pihak lain juga perlu memberikan bantuan akses layanan TBC-RO di fasilitas layanan kesehatan (fasyankes) yang mampu dijangkau oleh pasien TBC-RO.

Dalam melakukan motivasi bagi pasien atau penderita TBCRO, organisasi mantan pasien hadir sebagai pihak yang pernah atau berpengalaman terjun langsung dalam proses pengobatan TBC-RO hingga tuntas. Di Indonesia, terdapat 16 organisasi mantan pasien di 12 provinsi di Indonesia. Sementara, 6 provinsi mendapatkan dukungan atau intervensi dari CTB dalam hal pengembangan organisasi mantan pasien serta dukungan lainnya. Keduabelas organisasi mantan pasien tersebut yakni PESAT (Sumatera Utara), PUSAKO (Sumatera Barat), STORY (Kepulauan Riau), BEKANTAN (Banjarmasin), KAREBA BAJI dan DAENG TBC (Sulawesi Selatan), CTP (Papua), GAMELAN TBC (Bali), BERAKSI (NTT), PANTHER, REKAT, PETIR, dan SEKAWANS (Jawa Timur), SEMAR (Jawa Tengah), TERJANG (Jawa Barat), dan PETA (DKI Jakarta). Organisasi mantan pasien inilah yang melakukan sejumlah kegiatan dalam rangka melakukan dukungan pengobatan serta pendampingan terhadap pasien TBC-RO mulai dari menggerakkan masyarakat untuk terlibat aktif dalam penanggulangan TBC, hingga meningkatkan akses layanan bagi pasien TBC-RO. 
Dalam kegiatannya, peran komunikasi yang efektif menjadi sangat penting. Mantan pasien yang tergabung dalam organisasi dituntut memiliki kemampuan komunikasi interpersonal yang baik sehingga pesan berupa motivasi pengobatan bagi pasien tersampaikan tanpa gangguan (noise) yang berarti. Satu hal yang menjadi modal besar bagi anggota mantan pasien yakni adanya pengalaman yang sama atau sebidang mengenai penanganan diri dalam menyelesaikan pengobatan TBC-RO yang tidak mudah. Hal ini kemudian disebut sebagai field of experience atau pengalaman hidup, persepsi, sikap, nilai-nilai, dan kepercayaan yang mempengaruhi cara berkomunikasi seseorang.

Latar belakang permasalahan tersebut kemudian mengerucutkan persoalan yang akan dikaji dalam tulisan ini yakni tentang bagaimana organisasi mantan pasien melakukan komunikasi interpersonal secara efektif untuk menyampaikan motivasi yang kuat kepada pasien TBC-RO sehingga memiliki kesadaran dan kekuatan yang tinggi hingga menyelesaikan pengobatan TBC-RO. Apa saja upaya dan bagaimana kegiatan komunikasi berbasis kesamaan pengalaman memberikan arti penting bagi pasien TBC-RO dalam menyelesaikan pengobatannya?

\section{METODOLOGI PENELITIAN}

Penelitian ini menggunakan metode kualitatif, pengumpulan data dengan melakukan wawancara mendalam (indepth interview), serta studi dokumen. Fokus penelitian berisi pokok 
kajian tentang bagaimana faktor dukungan organisasi mantan pasien sebagai bagian dari komunitas masyarakat mempengaruhi pasien TBC-RO untuk lebih termotivasi dalam menjalani dan menyelesaikan rangkaian pengobatan yang tidak mudah. Penelitian ini juga akan membahas bagaimana kesamaan field of experience yang dimiliki oleh komunikator dan komunikan berperan penting dalam upaya motivasi dan pendampingan pengobatan bagi pasien TBC-RO.

Informan atau narasumber diambil dari perwakilan 16 organisasi mantan pasien yang tersebar di 12 provinsi di Indonesia (terdapat 6 wilayah provinsi intervensi CTB). Adapun informan utama dalam penelitian ini adalah anggota organisasi mantan pasien yang terlibat dalam kegiatan-kegiatan pengobatan dan pendampingan pasien TBC-RO, terutama Terus Berjuang (TERJANG) dari provinsi Jawa Barat dan Pejuang Tangguh (PETA) di provinsi DKI Jakarta. Analisis data yang digunakan adalah dengan menelaah seluruh data yang tersedia dari hasil wawancara dengan melakukan reduksi data dalam sebuah rangkuman.

\section{PEMBAHASAN}

Field of Experience, Modal Besar Organisasi Mantan Pasien TBC-RO

Organisasi mantan pasien berisi sekumpulan mantan pasien TBC-RO yang telah berhasil menyelesaikan pengobatannya baik melalui pengobatan jangka panjang selama kurang lebih 2 tahun 
atau menggunakan obat baru Bedaquiline dan Delamanid dengan lama pengobatan yang relatif lebih singkat. Beberapa di antara pengurusnya juga merupakan orang awam yang belum berpengalaman terlibat di organisasi. Hingga 2019, terdapat 16 organisasi pasien di 12 provinsi yang telah diakui dan memiliki surat keputusan, sementara organisasi pasien di 6 provinsi berada di bawah intervensi CTB, termasuk di dalamnya PETA (DKI Jakarta) dan TERJANG (Jawa Barat).

TERJANG misalnya, telah secara resmi terdaftar di Kementerian Hukum dan HAM No. AHU-0031864.AHA.01.12 TAHUN 2016 Tanggal 26 Juli 2016 sebagai organisasi yang lebih terstruktur dan memiliki rencana kerja yang lebih luas. Dalam struktur organisasinya, anggota organisasi mantan pasien kemudian disebut sebagai pendidik sebaya yang akan menjalankan peran edukasi TBC-RO kepada pasien.

Pejuang Tangguh TBC-RO Jakarta (PETA) memiliki visi yakni terwujudnya PETA sebagai yayasan yang lebih profesional dan sukses dalam berperan membantu memberikan dukungan psikososial yang efektif dan efisien bagi terduga dan pasien TBC, khususnya TBC-RO di Jabodetabek serta mengurangi laju infeksi TBC-RO di massyarakat. Sementara Organisasi Mantan Pasien Terus Berjuang (TERJANG) memiliki visi untuk menuju Jawa Barat bebas TBC, didukung dengan beberapa misi pendampingan pasien yakni memberikan dukungan psikososial dan motivasi kepada semua pasien TBC-RO dalam menjalani pengobatan, meningkatkan komitmen pasien dalam berobat sampai 
penngobatan lengkap dan dinyatakan sembuh, melakukan pelacakan ketika ada pasien "delay treatment", "mangkir", dan "loss to follow up" untuk dapat melanjutkan pengobatan TBC-RO sampai lengkap dan dinyatakan sembuh, hingga meningkatkan pengetahuan tentang TBC melalui komunikasi, informasi, dan edukasi (KIE) yang tepat dan benar kepada pasien dan kontak erat.

Pada 2019, TERJANG memperluas area kerjanya hingga ke Kabupaten Bandung, Bandung Barat, Karawang, Sukabumi, Tasikmalaya, dan Sumedang. Untuk mendukung visi dan misi ini, terutama dalam hal meningkatkan kemampuan komunikasi dan edukasi, sejumlah peningkatan kapasitas mantan pasien sangat diperlukan.

Pada 2015, beberapa organisasi mantan pasien dari berbagai provinsi tersebut bergabung membentuk Perhimpunan Organisasi Passien Tuberkulosis (POP TB) bekerjasama dengan CTB dengan pendanaan dari USAID Indonesia. Selain itu, terdapat Lembaga Kesehatan Nahdlatul Ulama (LKNU) dan Aisyiyah yang turut mengembangkan berbagai jenis kegiatan organisasi mantan pasien. Organisasi mantan pasien merupakan mitra yang sangat potensial untuk mendukung upaya kesembuhan pasien dan menjangkau populasi yang rentan terhadap penularan TBC, terutama TBC-RO.

Bukan tanpa peningkatan kapasitas, mantan pasien yang tergabung dalam organisasi juga kerap mendapatkan pengembangan kapasitas organisasi dan pelatihan bagi anggota 
hingga mendorong pelibatannya dalam beberapa kegiatan pengambilan kebijakan mengenai penanganan TBC-RO di Indonesia. Lebih jauh lagi, mantan pasien TBC-RO juga pernah terpilih sebagai salah satu anggota Green Light Committee wilayah Asia Tenggara 2019-2020 dalam rangka mereview serta berdiskusi mengenai informasi ilmiah dan berbagi pengalaman profesional para mantan pasien dalam upayanya menanggulangi TBC-RO.

Sedemikian pentingnya peran mantan pasien bersama dengan organisasinya, sedemikian penting pula pengembangan kapasitas para anggotanya dalam menggenjot upaya penanggulangan TBCRO dan menuju Indonesia Bebas TBC 2030. Hal tersebut menjadi modal besar bagi para mantan pasien untuk memainkan perannya ketika menjadi pendidik sebaya dan memberikan dukungan moral serta pendampingan bagi pasien TBC-RO dalam menyelesaikan pengobatan. Kemampuan berkomunikasi didukung dengan pengetahuan yang bersumber dari peningkatan kapasitas mantan pasien sangat membantu dalam penyampaian pesan mengenai TBC-RO kepada pasien.

Adapun beberapa kegiatan yang memungkinkan terjadinya proses komunikasi atau penyampaian pesan oleh para mantan pasien kepada pasien TBC-RO secara umum yakni:

1. Hospital Visit atau kunjungan rumah sakit, digunakan sebagai edukasi pasien baru dan yang sedang menjalani pengobatan dan diskusi kelompok sebaya 
2. Puskesmas Visit, digunakan oleh pendidik sebaya untuk edukasi dan diskussi dengan kader dan pasien di Puskesmas serta memberikan feedback dari diskusi dengan pasien ke pihak Puskesmas

3. Home Visit, yang bertujuan meningkatkan kepatuhan berobat bagi pasien TBC-RO dengan cara memberikan dukungan berupa pengetahuan dan motivasi. Dalam kegiatan ini, pendidik sebaya melakukan pendampingan pasien TBC-RO, baik dalam persiapan pengobatan, maupun dalam pengobatan sampai dinyatakan sembuh. Pendidik sebaya juga diberdayakan dalam proses investigasi kontak, yakni kunjungan ke rumah pasien TBC dan kontak terdekat yang berisiko. Kegiatan ini biasanya dilakukan secara kerjasama antara pendidik sebaya dan Puskesmas/Posyandu.

4. Pendidik sebaya mantan pasien juga kerap melakukan program pemberian nutrisi kepada pasien TBC-RO.

Gambar 1 Mantan Pasien dari TERJANG mengedukasi pasien TBC-RO

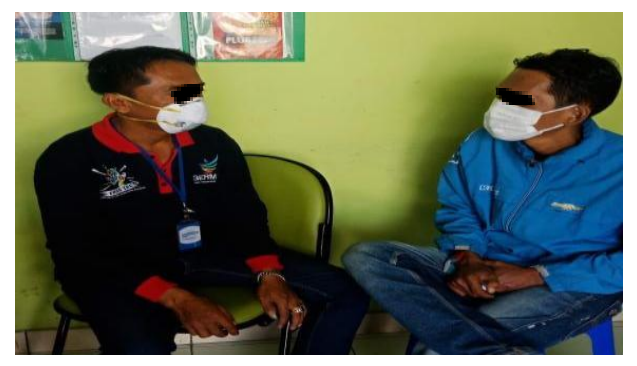

Sumber: Dok. TERJANG Jawa Barat, 2019

Ketika mantan pasien atau pendidik sebaya sebagai komunikator bertemu dengan pasien sebagai komunikan, kedua 
pihak saling bertukar informasi. Informasi yang ada menjadi landasan untuk membentuk tujuan yang sama yakni berupa kesepakatan dari proses komunikasi kedua. Komunikasi dalam proses motivasi, edukasi, dan pendampingan pasien TBC-RO ini mencakup komunikasi interpersonal. Komunikasi interpersonal yang berjalan aktif ketika komunikasi berlangsung membantu seseorang untuk merasa lebih baik secara fisik dan psikologis (Bernardus, 2016; West dan Turner, 2009).

Komunikasi interpersonal atau antarpribadi merupakan komunikasi antara orang-orang dengan cara tatap muka sehingga memungkinkan pesertanya menangkap reaksi secara langsung baik verbal maupun non-verbal (Mulyana, 2010). Mulyana juga menyebutkan bahwa peserta komunikasi menjadi kunci kualitas dan intimitas komunikasi interpersonal. Sebab, dalam prosesnya komunikasi interpersonal atau diadik dilakukan untuk menimbulkan kesalingan dalam penciptaan makna sehingga satu frekuensi dan pemahaman dalam berkomunikasi secara tatap muka dengan jarak akrab (Tarsani, 2016).

Bagaimanapun, komunikasi interpersonal erat dengan relasi yang terjalin antara komunikator dengan komunikan dan berjalan sesuai dengan kondisi dari peserta. Dalam komunikasi jenis ini erat kaitannya dengan latar belakang individu, di mana pengetahuan, persepsi, serta budaya sangat memberikan pengaruh bagi kualitas komunikasi antara komunikator dan komunikan. Dalam studi ini, latar belakang pengetahuan dan pengalaman yang berujung pada persepsi sangat memberikan pengaruh yang 
berarti bagi komunikasi mantan pasien terhadap pasien TBC-RO yang sedang dalam perjuangannya menyelesaikan pengobatan. Adapun keberhasilan komunikasi interpersonal dalam mengedukasi pasien TBC-RO dikarenakan adanya kasih sayang, dan komunikasi yang terjalin secara lebih rileks (relaksasi). (Astuti; Bajari; Rachmiatie; Venus, 2019).

Mantan pasien yang berperan juga sebagai pendidik sebaya berjalan bersama memberikan motivasi pasien TBC-RO karena adanya kesamaan pengalaman. Dalam model komunikasi Wilbur Schramm, kesamaan pengalaman ini kemudian disebut sebagai field of experience. Hal ini merupakan komponen yang melengkapi dalam komunikasi selain unsur sender, message, decoder, encoder, dan signal. Schramm juga menyebutkan bahwa komunikasi akan berhasil apabila pesan yang disampaikan oleh komunikator cocok dengan kerangka acuan (frame of refference) yakni panduan pengalaman dan pengertian yang pernah diperoleh komunikan di bidang pengalaman (field of experience) merupakan faktor yang penting dalam komunikasi (Effendy, 2006). Sehingga ketika terdapat kesamaan pengalaman, maka umpan balik atau feedback yang diharapkan oleh peserta komunikasi akan muncul dan menciptakan komunikasi yang efektif. 


\section{Gambar 2 Field of Experience dalam Model Komunikasi Schramm}

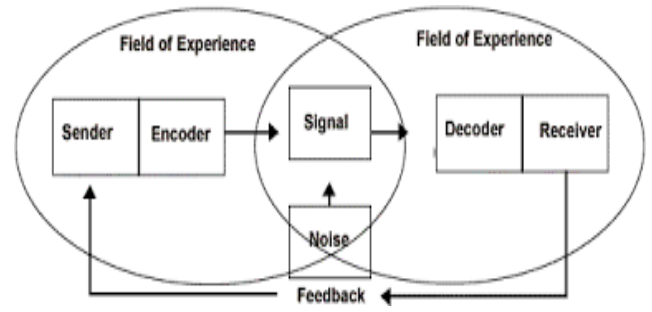

Sumber: Deddy Mulyadi, 2010

Motivasi yang diberikan oleh pendidik sebaya merupakan pesan yang disampaikan oleh mantan pasien yang memiliki pengalaman pengobatan TBC-RO. Sender (mantan pasien/pendidik sebaya) memulai menyusun sandi (encoding) di mana kumpulan sandi tersebut akan menjadi sebuah konsep pesan (message 1). Kemudian pesan tersebut sebelum diterima oleh pasien TBC-RO (receiver) secara otomatis pasien TBC-RO (receiver) akan menguraikan sandi (decoding) tersebut. Pada arus komunikasi timbal balik pastinya pasien TBC-RO (receiver) yang awalnya sebagai receiver akan berganti peran sebagai source.

Kemudian pasien TBC-RO (receiver) menyusun sandi (encoding) yang akan menjadi konsep pesan (message 2). Pada proses encoding ini, seseorang menyusun sandi-sandi dipengaruhi perpaduan dua hal yaitu Frame of Reference (kerangka berpikir seseorang) dan Field of Experience (bidang pengalaman seseorang). Kemudian setelah pasien TBC-RO (receiver) menyusun sandi (encoding) dan mampu membuat pesan (message 2) maka pesan ini pun akan diuraikan kembali 
(decoding) oleh receiver. Dalam proses decoding tentunya receiver juga dipengaruhi oleh field of experience dan frame of reference. Setelah pesan (message 2) sampai pada receiver, maka akan terjadi dua kemungkinan, yakni apabila frame of reference dan field of experience antara mantan pasien (sender) dengan pasien TBC-RO (receiver) sama maka akan terjadi Homophily, sebaliknya jika yang ada adalah perbedaan frame of reference dan field of experience (Heterophily) maka diperlukan mediator untuk membantu proses komunikasi antara peserta komunikasi.

Setelah pesan (message 2) sampai ke pasien TBC-RO (receiver) maka untuk menimbulkan komunikasi yang berlanjut, antara receiver dan sender harus mencapai titik yang dinamakan Overlapping of Interest, yaitu titik kesamaan pola pikir (frame of reference) dan pengalaman (field of experience) antara komunikator dengan komunikan sebagai peserta komunikasi. Ketertarikan tersebut (overlapping of interest) dapat digambarkan dengan Ven. Kelebihan dari organisasi mantan pasien sebagai pendidik sebaya yakni memiliki bidang pengalaman yang sama sehingga mudah dalam menyampaikan pesan dan mencapai titik kesamaan pola pikir secara efektif tanpa terlalu memerlukan mediator.

Kendati demikian, dalam proses komunikasi, noise juga dimungkinkan tidak luput, misalnya ketika pendidik sebaya mencoba memotivasi pasien mangkir berobat TBC-RO, akan ada noise berupa ketidaksanggupan pasien TBC-RO melanjutkan pengobatan karena sejumlah efek samping mulai dari fisik, 
mental, dan efek samping sosial. Hal ini yang kemudian kembali didiskusikan antara pendidik sebaya mantan pasien dengan pasien TBC-RO.

Mantan pasien juga dapat memberikan advokasi ketika menemukan noise semacam itu, baik advokasi untuk memudahkan pasien mendapatkan akses layanan pasien TBC-RO di fasilitas layanan kesehatan (fasyankes). Dalam proses penelitian kerap ditemukan contoh bahwa pasien TBC-RO terlalu jauh untuk menjangkau fasyankes yang menyediakan layanan TBC-RO secara komprehensif, sehingga putus berobat sangat mungkin ditemui. Di sinilah peran organisasi mantan pasien dalam memastikan bahwa pasien TBC-RO mendapatkan akses layanan TBC-RO semudah mungkin sehingga mendukung proses pengobatannya.

\section{KESIMPULAN DAN SARAN}

Organisasi mantan pasien yang berisi mantan pasien (pendidik sebaya) terbentuk sebagai upaya untuk memudahkan pasien TBC-RO dalam mengakses layanan TBC-RO di fasyankes. Fungsi lainnya yang juga sangat esensial adalah mendampingi pasien dalam mengakses layanan pengobatan serta mengedukasi pasien TBC-RO sehingga menyelesaikan pengobatan. Hal demikian diperlukan sebab menyelesaikan pengobatan TBC-RO tidaklah mudah. Terdapat banyak efek samping dari pengobatan yang kurang lebih harus diselesaikan selama dua tahun. 
Dalam menjalankan perannya sebagai pendidik sebaya dalam mengedukasi dan memotivasi, kemampuan komunikasi sangat diperlukan. Adanya kesamaan Field of experience antara mantan pasien (komunikator) dan pasien TBC-RO (komunikan) memberikan kemudahan tersampaikannya pesan secara efektif karena mantan pasien secara praktis akan menuangkan pengalamannya menjalani pengobatan sebagai materi edukasi. Sementara sesuai dengan teori Message Design Logic, gaya logika retoris sangat relevan dalam menggambarkan peran mantan pasien ketika mengedukasi yang lebih luwes dan berwawasan (hal ini turut dipengaruhi oleh modal kesamaan field of experience), serta mantan pasien lebih berorientasi kepada penyampaian tujuan dibanding sekadar terciptanya respons dari komunikan (pasien TBC-RO). Hal ini kemudian memberikan pengaruh positif terhadap meningkatnya angka kepatuhan pasien yang didampingi oleh pendidik sebaya, yakni menjadi 76-81\%. Dapat dikatakan bahwa kesamaan field of experience yang dilengkapi dengan gaya komunikasi logika retoris menjadi alternatif pilihan komunikasi yang baik dalam meningkatkan kepatuhan pasien menyelesaikan pengobatan TBC-RO. 


\section{DAFTAR PUSTAKA}

Albrecht, L; Terrance and Peterson, W, L. (1996). Message Design Logic, Social Support, and Mixed-Status Relationship, Western Journal of Communication, 60(4), 291-309

Astuti, Sri Wahyuning; Bajari, Atwar; Rachmiatie, Atie; Venus, Anter. (2019). Hubungan antara Motif Komunikasi Interpersonal dan Kepuasan Komunikasi Antar Pribadi Generasi Milenial, Jurnal PROMEDIA, 5(2), 171-206

Budianto, Imanuel. (2013). Proses Komunikasi Interpersonal antara Guru dengan Murid Penyandang Autis di Kursus Piano Sforzando Surabaya, Jurnal E-Komunikasi, 1(2), 90-112

Gebhard, Agnes, dkk. (2019). Finding The Missing TB Patients In Indonesia: Good Practices 2015-2017: A Case Study on The Role of The USAID-Funded Challenge TB Project In Increasing TB Case Notification in Indonesia. Jakarta: Challenge TB KNCV

Nugroho, Randy Adhi. (2011). Studi Kualitatif Faktor yang Melatarbelakangi Drop Out Pengobatan Tuberkulosis Paru, Jurnal Kesehatan Masyarakat, 7(1), 83-90

O'Keefe, B. J. (1988). The logic of message design: Individual Differences in Reasoning about Communication. Communication Monographs, 55(1), 80-103

Peranginangin, Bastanta Bernardus. (2016). Model Komunikasi Interpersonal Generasi Muda Suku Batak Karo di Yogyakarta Melalui Tradisi Ertutur, Jurnal Aspikom, 2(6), 425-436

Riyadi, Ilham. (2018). Analisis Strategi Komunikasi Community TB-HIV Care Aisyiyah In Mentorship of TB-MDR Patients at RSUD Labuang Baji Makassar, Jurnal Kareba, 7(2), 256-263

Tarsani. (2016). Peran Customer Service dalam Meningkatkan Kepuasan Pelanggan Melalui Pendekatan Komunikasi Antar Pribadi, Jurnal BRICOLAGE, 2(1) 46-55

Yasin, Muhamad. (2012). Analisis Gaya Komunikasi Guru Matematika Berdasarkan Teori Komunikasi Logika 
Desain Pesan (Studi Kasus pada SMP dan MTs di Kecamatan Mranggen) (h. 591-598). Yogyakarta

\section{Dokumen resmi:}

Office of Infectious Disease. (2018). Panduan Keperawatan untuk Manajemen Efek Samping Pengobatan Tuberkulosis Resisten Obat. Indonesia: USAID Challenge TB

Direktorat Jenderal Pencegahan dan Pengendalian Penyakit

Kementerian Kesehatan Republik Indonesia. (2018). Petunjuk Teknis Investigasi Kontak Pasien TBC Kerja Sama Petugas Kesehatan dan Komunitas. Jakarta: Kemenkes RI

\section{Artikel dalam Internet:}

Tanpa nama. (2018). TBC, Stunting, Imunisasi Jadi Prioritas Pengawasan Itjen. (2019 Desember 25). Diakses dari https://www.depkes.go.id/article/view/1803 1500003/tbcstunting-imunisasi-jadi-prioritas-pengawasan-itjen.html

Tanpa nama. (2019). Berjalan Bersama Organisasi Mantan Pasien untuk Mengakhiri Tuberkulosis di Indonesia. (2019 Desember 26). Diakses dari https://www.stoptbindonesia.org/single-post/2019/ 01/11/Berjalan-Bersama-Organ isasi-Mantan-PasienUntuk- Mengakhiri-Tuberkulosis-di-Indonesia?lang=en

Sarah Ervina. (2019). Angka Keberhasilan Pengobatan TB MDR Rendah, Cek Alasannya. (2019 Desember 26). Diakses dari https://gaya.tempo.co/read/1254 399/angkakeberhasilan-pengobatan-tb-mdr-rendah-cekalasannya/full? view $=\mathrm{ok}$ 